\title{
COMPETITIVE INTERACTION BETWEEN TWO S ALLELES IN A SPOROPHYTICALLY-CONTROLLED INCOMPATIBILITY SYSTEM
}

\author{
K. F. THOMPSON \\ Plant Breeding Institute, Trumpington, Cambridge
}

Received 13.iii.71

\section{INTRODUGTION}

Competrtive interaction between $S$ alleles in diploid pollen of artificiallyinduced or spontaneous autotetraploids has been reported only in species in which self-incompatibility is gametophytically controlled. This interaction, which is known also as mutual weakening of the activities of both alleles of an $S$ allele heterozygote, produced self-compatibility in an autotetraploid pear (Lewis and Modlibowska, 1942) and in Trifolium repens (Brewbaker, 1954). In Oenothera organensis it permitted only the longer growth of pollen tubes (Lewis, 1947). Brewbaker and Natarajan (1960) reported that competitive interaction characterised diploid pollen grains in all $S$ allele heterozygotes tested in Petunia inflata. Similarly the self-compatibility of some mutants induced by radiation of the pollen of self-incompatible $S$ allele heterozygotes in Petunia was explained by competitive interaction between different $S$ alleles, one of which was carried by a centre fragment produced by the irradiation.

Tetraploid Brassicas, produced by colchicine treatment, were found by Howard (1942) to remain self-incompatible and it has been considered to be characteristic of sporophytically-determined incompatibility systems that competitive interaction between $S$ alleles does not occur at either the diploid or tetraploid levels. Crowe (1964) suggested that, in the evolution of sporophytic from gametophytic incompatibility, selection would act against any alleles displaying competitive interaction. In a study of 128 combinations between $28 S$ alleles in Brassica oleracea var. acephala, in which selfincompatibility is sporophytically determined, Thompson and Taylor (1966a) found results suggesting competitive interaction for one combination only. These results, which have been summarised by Thompson (1967), are considered in more detail below because of their uniqueness and importance.

\section{MAterial AND methods}

The marrow-stem kale inbreds were obtained by selfing plants selected from a stock produced by Cannell and Sons. The curled kale was selected from plants grown from a packet of Scotch curled kale purchased at Woolworths.

Pollination methods were similar to those described in Thompson and Taylor (1971). Observations on darkening of stigmas were used to detect compatible pollinations in some of the families investigated (Thompson and Howard, 1959; Thompson and Taylor, 1966a, b). 


\section{Results}

(a) Progeny from a cross between curled and marrow-stem kale

The self-incompatible curled kale selection, plant $\mathrm{Cr}_{1}$, was found by Thompson and Taylor (1971) to have the two alleles, $S_{15}$ and $S_{35}$ (the latter allele had not been identified previously). It was crossed with the selfincompatible marrow-stem kale inbred, plant 220/1, which is homozygous for allele $S_{2}$. Three of the five $F_{1}$ hybrids were self-compatible and set seed freely in the insect-proofed glasshouse without hand pollination. On crossing the $F_{1}$ hybrids as males to inbred 220/1 (the $S_{2}$ homozygote), the stigmas darkened only with the two self-incompatible plants. The non-darkening with the self-compatible $\mathrm{F}_{1}$ plants showed that allele $S_{2}$ was active in their pollen.

From one of the self-compatible $F_{1}$ hybrids, plant $Z 209 / C, 14$ plants of the $\mathrm{F}_{2}$ generation were selected on the basis of the chemical composition of the pith of their stems. These plants were selfed at the mature flower stage and in the bud and tested for $S$ alleles (table 1). Four plants were self-compatible, one (Z209/20) was partially self-compatible and the other nine were selfincompatible.

\section{TABLE 1}

Segregation for self-compatibility and $\mathrm{S}$ alleles in selected progeny from selfing the self-compatible plant Z209/C

\begin{tabular}{|c|c|c|c|}
\hline \multirow[b]{2}{*}{$\begin{array}{l}\text { Progeny } \\
\text { No. }\end{array}$} & \multicolumn{2}{|c|}{$\begin{array}{l}\text { Average no. seeds/fruit from } \\
\text { selfing }\end{array}$} & \multirow[b]{2}{*}{$\begin{array}{l}S \text { allele } \\
\text { constitution }\end{array}$} \\
\hline & $\begin{array}{l}\text { at mature } \\
\text { flower }\end{array}$ & $\begin{array}{l}\text { in the } \\
\text { bud }\end{array}$ & \\
\hline $\begin{array}{r}1 \\
6 \\
12 \\
13\end{array}$ & $\begin{array}{l}26 \cdot 3 \\
20 \cdot 8 \\
21 \cdot 2 \\
12 \cdot 5\end{array}$ & $\begin{array}{l}23 \cdot 7 \\
16 \cdot 2 \\
30 \cdot 0 \\
13 \cdot 2\end{array}$ & 2,15 \\
\hline $\begin{array}{r}3 \\
5 \\
15 \\
17 \\
20 \\
22 \\
23 \\
24\end{array}$ & $\begin{array}{r}0.2 \\
0.0 \\
1.3 \\
3.5 \\
10.2 \\
1.5 \\
0.0 \\
1.8\end{array}$ & $\begin{array}{r}16.2 \\
6.5 \\
13.5 \\
22.8 \\
17 \cdot 6 \\
19.5 \\
7.5 \\
20.7\end{array}$ & 2,2 \\
\hline $\begin{array}{r}4 \\
16\end{array}$ & $\begin{array}{l}0 \cdot 0 \\
2 \cdot 7\end{array}$ & $\begin{array}{l}27 \cdot 8 \\
12 \cdot 5\end{array}$ & 15,15 \\
\hline
\end{tabular}

The stigmas of all the $\mathrm{F}_{2}$ plants darkened when they were crossed by the unrelated inbred, plant A162/2/1, which is homozygous for $S_{16}$. Testing for alleles present in these plants was therefore possible using stigma darkening as the criterion of compatible pollinations (checks were made, however, by noting fruit development after 5 weeks; seed counts were not made). The stigmas of only two plants, Z209/4 and Z209/16, darkened after pollination with inbred 220/1 (the $S_{2}$ homozygote). These two plants, both of which were self-incompatible, are the homozygotes for $S_{15}$ the recessive (low in the dominance series) allele of plant $\mathrm{Cr}_{1}$. 
The stigmas of eight seedlings darkened after pollination by Z209/4 (homozygous for $S_{15}$, see above). These eight plants, which were all selfincompatible with the exception of plant 20, which was partially selfcompatible, are the homozygotes for allele $S_{2}$.

The remaining four plants, the stigmas of which did not darken after pollination with either $220 / 1$ or Z209/4, are the $S_{2} S_{15}$ heterozygotes, both alleles being active in the stigma. They were all self-compatible (table 1 ), i.e. there must be competitive interaction between the two $S$ alleles in the pollen or a factor conditioning self-compatibility and independent of the $S$ allele system must be present. Although darkening of the stigma did not occur after pollinations with plants 220/1 and Z209/4, some seeds were set. In the self-incompatible plants, on the other hand, appreciable seed setting occurred only after darkening of stigmas.

In the following year a further $18 \mathrm{~F}_{2}$ plants were selected on vigour and chemical composition from a progeny of the same self-compatible $F_{1}$ hybrid, Z209/C. The plants were selfed at the mature flower stage and in the bud and crossed with inbreds, homozygous for alleles $S_{2}, S_{15}$ and $S_{16}$ (table 2). The results differ somewhat from those obtained the previous year (table 1). The 12 plants heterozygous for alleles $S_{2}$ and $S_{15}$ consisted of eight selfcompatibles and four which were only partially self-compatible. The three plants, homozygous for $S_{2}$, and the three homozygous for $S_{15}$ were all highly self-incompatible. One of the partially self-compatible plants, Z209/118, gave $3 \cdot 2,20.5$ and 26.0 seeds per fruit when crossed with inbreds, homozygous for alleles $S_{2}, S_{15}$ and $S_{16}$ respectively; no darkening of the stigma was observed in the $S_{15}$ cross. It would appear, therefore, that in the partially self-compatible plant $S_{2}$ was incompletely dominant in the stigma to $S_{15}$.

Confirmation of partial self-compatibility in plant 106 by a later pollination (table 2) suggests that genetic rather than environmental factors determined the change in dominance relationships and expression of selfcompatibility. As five of the $21 S$ allele heterozygotes were partially selfcompatible the effect could have been determined by a single recessive gene.

Further unselected $F_{2}$ generation plants from selfing $\mathrm{Z} 209 / \mathrm{C}$ were studied (table 3). The two plants (133 and 146), which were homozygous for allele $S_{15}$, showed stigma darkening and produced as high a set of seeds when pollinated with any of three plants $\left(135,138\right.$ and 148), heterozygous for $S_{2}$ and $S_{15}$, as they did when pollinated with an unrelated inbred, homozygous for $S_{16}$. Both plants were highly self-incompatible and the crossing results suggest that $S_{2}$ was dominant to $S_{15}$ in the pollen.

The two plants (151 and 153), which were homozygous for allele $S_{2}$, differed, one plant being self-compatible and the other self-incompatible. Both plants gave high sets of seed per fruit when pollinated by the three plants, heterozygous for $S_{2}$ and $S_{15}$, although there was some reduction in number of seeds for two of the crosses with the self-incompatible plant. Neither of the self-compatible or self-incompatible plants showed darkening of the stigma. These results would suggest either that $S_{15}$ was incompletely dominant to $S_{2}$ in the pollen, disagreeing with the conclusion in the previous paragraph or that competitive interaction between alleles $S_{2}$ and $S_{15}$ occurred in the pollen. In the latter case, plant 138 showed greater competitive interaction than plants 135 and 148. The difference in seed set between plants 151 and 153 in crosses with plants 135 and 148 may be due to the self-compatibility of plant 151 . 
Four self-compatible plants (135, 138, 145 and 148), which were $S_{2} S_{15}$ heterozygotes, set relatively high numbers of seeds per fruit when pollinated by the two plants (151 and 153), homozygous for $S_{2}$, and the two plants (133 and 146), homozygous for $S_{15}$. For these pollinations flowers were emasculated before pollen was shed. It should be noted that although plant 15l, homozygous for $S_{2}$, was self-compatible, the seed set from pollinations by the four plants, homozygous for $S_{2}$ or $S_{15}$, were consistently lower than seed set on selfing the $S_{2} S_{15}$ heterozygotes. The partially self-compatible plant (142) set a high number of seed when pollinated by the $S_{15}$ homozygotes but a relatively low number, similar to those from selfing, when pollinated

TABLE 2

Segregation for self-compatibility and $\mathrm{S}$ alleles in further selected progeny from selfing plant Z209/C

\begin{tabular}{|c|c|c|c|}
\hline \multirow[b]{2}{*}{$\begin{array}{l}\text { Progeny } \\
\text { No. }\end{array}$} & \multicolumn{2}{|c|}{$\begin{array}{l}\text { Average no. seeds/fruit from } \\
\text { selfing }\end{array}$} & \multirow[b]{2}{*}{$\begin{array}{l}S \text { allele } \\
\text { constitution }\end{array}$} \\
\hline & $\begin{array}{l}\text { at mature } \\
\text { flower }\end{array}$ & $\begin{array}{l}\text { in the } \\
\text { bud }\end{array}$ & \\
\hline $\begin{array}{l}105 \\
107 \\
108 \\
109 \\
124 \\
126 \\
130 \\
131\end{array}$ & $\begin{array}{l}26.5 \\
22.0 \\
32 \cdot 2 \\
28.5 \\
23.3 \\
21 \cdot 8 \\
19 \cdot 7 \\
20.0\end{array}$ & $\begin{array}{l}26 \cdot 7 \\
25 \cdot 6 \\
29 \cdot 6 \\
27 \cdot 7 \\
29 \cdot 2 \\
26.9 \\
25 \cdot 3 \\
29 \cdot 7\end{array}$ & 2,15 \\
\hline $\begin{array}{l}106 \\
106 \\
118 \\
125 \\
127\end{array}$ & $\begin{array}{l}5 \cdot 5 \\
7 \cdot 9 * \\
5 \cdot 5 \\
6 \cdot 1 \\
4 \cdot 0\end{array}$ & $\begin{array}{l}26 \cdot 6 \\
23 \cdot 8^{*} \\
26 \cdot 2 \\
26 \cdot 6 \\
14 \cdot 2\end{array}$ & 2,15 \\
\hline $\begin{array}{l}123 \\
128 \\
129\end{array}$ & $\begin{array}{l}0.0 \\
1.0 \\
2 \cdot 1\end{array}$ & $\begin{array}{l}20 \cdot 9 \\
27 \cdot 5 \\
25 \cdot 0\end{array}$ & 2,2 \\
\hline $\begin{array}{l}103 \\
114 \\
136\end{array}$ & $\begin{array}{l}0.0 \\
0.0 \\
0.1\end{array}$ & $\begin{array}{r}30.9 \\
8.7 \\
11.3\end{array}$ & 15,15 \\
\hline
\end{tabular}

with the two $S_{2}$ homozygotes. This result is similar to those obtained earlier with the partially self-compatible $S$ allele heterozygote (plant 118), in which $S_{2}$ was incompletely dominant in the stigma to $S_{15}$.

Taken together all the above results indicate that alleles $S_{2}$ and $S_{15}$ must interact in both pollen and stigma so that self-compatibility occurs or that there is a factor independent of the $S$ allele system determining self-compatibility. The curled kale parent plant, $\mathrm{Cr}_{1}$, is heterozygous for a dominant self-compatibility gene independent of the $S$ allele system which gives selfcompatibility only in the absence of the dominant $S$ gene (Thompson and Taylor, 1971). This gene is obviously not involved in the family from selfing Z209/C because all the $S_{15}$ homozygotes are self-incompatible and it is only the $S_{2} S_{15}$ heterozygotes which are self-compatible (tables 1 and 2). 
Self-compatibility could also result from reversed dominance of two $S$ alleles in pollen and stigma (Thompson and Howard, 1959). Based on the darkening of stigmas reactions, allele $S_{2}$ was completely dominant to $S_{15}$ in the pollen while both alleles were active in the stigma. Although allele $S_{2}$ was active in the stigma, self-compatibility could occur if it was incompletely recessive to $S_{15}$. Pollination of plants, heterozygous for $S_{2}$ and $S_{15}$, with $S_{2}$ and $S_{15}$ homozygotes, however, gave equal sets of seed (table $3 b$ ) showing that the self-compatibility of the heterozygotes was not determined by incomplete reversed dominance. More seeds per fruit were produced by selfing the heterozygotes at the mature flower stage than by pollinating with

TABLE 3

Reciprocal crosses between self-compatible and self-incompatible progeny from selfing Z209/C

(a) Crosses between plants, homozygous for $S$ alleles, as female, with plants, heterozygous for $S$ alleles, as male.

Average no. seeds/fruit

\begin{tabular}{|c|c|c|c|c|c|c|c|}
\hline \multirow[b]{2}{*}{$\begin{array}{c}\text { Progeny } \\
\text { No. }\end{array}$} & \multirow[b]{2}{*}{$S$ alleles } & \multirow{2}{*}{$\begin{array}{l}\text { by selfing } \\
\text { at mature } \\
\text { flower }\end{array}$} & \multirow{2}{*}{$\begin{array}{c}\text { Outcross } \\
\text { A } 162 / 2 / 1 \\
16,16\end{array}$} & \multicolumn{4}{|c|}{ Crossed by $S_{2} S_{15}$ plants as male } \\
\hline & & & & No. & $\begin{array}{r}135 \\
2,15\end{array}$ & $\begin{array}{r}138 \\
2,15\end{array}$ & $\begin{array}{r}148 \\
2,15\end{array}$ \\
\hline 133 & 15,15 & $0 \cdot 0$ & $30 \cdot 7$ & & $33 \cdot 4$ & $32 \cdot 4$ & $34 \cdot 5$ \\
\hline 146 & & 0.7 & $33 \cdot 0$ & & $30 \cdot 0$ & $36 \cdot 2$ & $34 \cdot 6$ \\
\hline 151 & 2,2 & $20 \cdot 1$ & $27 \cdot 3$ & & $26 \cdot 7$ & $24 \cdot 2$ & $23 \cdot 3$ \\
\hline 153 & & 0.8 & $25 \cdot 3$ & & $12 \cdot 0$ & $27 \cdot 2$ & $17 \cdot 7$ \\
\hline
\end{tabular}

(b) Crosses between plants, heterozygous for $S$ alleles, as female, with plants, homozygous for $S$ alleles, as male.

Average no. seeds/fruit

\begin{tabular}{|c|c|c|c|c|c|c|c|}
\hline \multirow[b]{2}{*}{$\begin{array}{c}\text { Progeny } \\
\text { No. }\end{array}$} & \multirow[b]{2}{*}{$S$ alleles } & \multirow{2}{*}{$\begin{array}{l}\text { by selfing } \\
\text { at mature } \\
\text { flower }\end{array}$} & \multicolumn{5}{|c|}{ Crossed as female by plants } \\
\hline & & & $\begin{array}{l}\mathrm{A} 162 / 2 / 1 \\
16,16\end{array}$ & $\begin{array}{l}151 \\
2,2\end{array}$ & $\begin{array}{l}153 \\
2,2\end{array}$ & $\begin{array}{r}133 \\
15,15\end{array}$ & $\begin{array}{r}146 \\
15,15\end{array}$ \\
\hline $\begin{array}{l}135 \\
135^{*}\end{array}$ & & $26 \cdot 7$ & $\frac{23 \cdot 1}{-}$ & $\begin{array}{l}16 \cdot 2 \\
18 \cdot 1^{*}\end{array}$ & $\begin{array}{l}17 \cdot 4 \\
21 \cdot 7 *\end{array}$ & $\begin{array}{l}15 \cdot 8 \\
16 \cdot 9 *\end{array}$ & $\begin{array}{l}17.5 \\
15 \cdot 9 *\end{array}$ \\
\hline 145 & 2,15 & $27 \cdot 7$ & 31.5 & 22.8 & - & 13.5 & 18.0 \\
\hline 148 & & $20 \cdot 9$ & $36 \cdot 5$ & $12 \cdot 8$ & - & $14 \cdot 2$ & $17 \cdot 4$ \\
\hline 138 & & $14 \cdot 4$ & $27 \cdot 6$ & $7 \cdot 3$ & - & 7.0 & 10.5 \\
\hline Mean & & $22 \cdot 4$ & $29 \cdot 7$ & $12 \cdot 8$ & 19.5 & $12 \cdot 6$ & $13 \cdot 3$ \\
\hline 142 & 2,15 & 5.5 & 31.5 & $5 \cdot 2$ & $5 \cdot 3$ & 29.5 & $29 \cdot 4$ \\
\hline
\end{tabular}

plants homozygous for $S_{2}$ or $S_{15}$, i.e. competitive interaction between alleles $S_{2}$ and $S_{15}$ occurred in the pollen as well as in the stigmas.

\section{Discussion}

In addition to the case of competitive interaction described in this paper for alleles $S_{2}$ and $S_{15}$ in kale, the data of Kakizaki (1930) for a self-compatible cabbage plant may afford another example. He found that plant 2, which was self-compatible, gave on selfing a progeny containing 13 self-compatible and 10 self-incompatible plants. Pollination between three of the selfincompatible inbreds showed that there were two reciprocally crosscompatible groups which were either the two homozygotes or a homozygote 
and a heterozygote with dominance in pollen and stigma. Self-compatibility could not therefore be due to an $S_{F}$ allele, nor was it likely to be caused by a dominant self-compatibility gene because 13 self-compatible: 10 selfincompatible is a very poor fit to a $3: 1$ segregation.

Thompson and Taylor (1971) explained the occurrence of selfcompatibility in kale using the hypothesis of Sampson (1960) to account for $S$ allele interactions. It was suggested that recessive $S$ alleles are relatively inefficient in the production of the substances responsible for incompatibility so that the threshold for the expression of self-compatibility was only just reached in plants homozygous for recessive $S$ alleles. In a serological study of self-incompatibility antigens from cabbage stigmas Wallace and Nasrallah (1968) found that the quantity of antigen produced by each $S$ allele in an $S$ allele heterozygote was only half that in an inbred homozygous for an $S$ allele. Thus a reduction of the quantity of each specific antigen in plants, heterozygous for two recessive alleles, could make these plants selfcompatible even though plants, homozygous for either $S$ allele, would be self-incompatible. If such were so, then competitive interaction to produce partial self-compatibility should occur fairly frequently between $S$ alleles low in the dominance series. A search specifically for competitive interaction between $S$ alleles has not been made in the kales ( $B$. oleracea var. acephala), but J. G. van Hal (personal communication, 30th December 1969), using ultraviolet fluorescence techniques to observe pollen tube growth, has found recently mutual weakening of activity in several combinations in Brussels sprouts $(B$. oleracea var. gemmifera).

\section{Summary}

1. In the $F_{2}$ generation from a cross between marrow-stem and curled kale, plants, heterozygous for the pollen-recessive $S$ alleles, $S_{2}$ and $S_{15}$, were self-compatible. Plants, homozygous for either allele, were self-incompatible.

2. Allele $S_{2}$ was completely dominant to $S_{15}$ in the pollen, but both alleles were active in the stigma. Equal numbers of seeds were set when $S_{2}$ or $S_{15}$ homozygotes were crossed as males to the heterozygote, but more seed was always set by selfing. Competitive interaction between $S_{2}$ and $S_{15}$ was assumed to occur in both pollen and stigmas of plants, heterozygous for these alleles.

3. In five partially self-compatible plants, heterozygous for $S$ alleles, allele $S_{2}$ was incompletely dominant to $S_{15}$ in the stigma. This change in self-compatibility and dominance relationships was probably determined by a recessive gene.

\section{REFERENCES}

BREWBAKER, J. L. 1954. Incompatibility in autotetraploid Trifolium repens. I. Competition and self-compatibility. Genetics, 39, 307-316.

BREWBAKER, J. L., AND NATARAJAN, A. T. 1960. Centric fragments and pollen-part mutation of incompatibility alleles in Petunia. Genetics, 45, 699-704.

CROWE, L. K. 1964. The evolution of outbreeding in plants. Heredity, 19, 435-457.

HOWARD, H. W. 1942. Self-incompatibility in polyploid forms of Brassica and Raphanus. Nature, Lond., 149, 302-303.

KAKIZAKI, Y. 1930. Studies on the genetics and physiology of self- and cross-incompatibility in cabbage ( $B$. oleracea var. capitata L). Jap. J. Bot., 5, 133-208. 
EEWIS, D. 1947. Competition and dominance of incompatibility alleles in diploid pollen. Heredity, 1, 85-108.

LEWIS, D., AND MODLIBOWSKA, I. 1942. Genetical studies in pears. IV. Pollen-tube growth and incompatibility. 7. Genet., 43, 211-222.

SAMPSON, D. R. 1960. An hypothesis of gene interaction at the $S$ locus in self-incompatibility systems of Angiosperms. Amer. Nat., 94, 283-292.

THOMPSON, K. F. 1967. Breeding problems in kale (Brassica oleracea) with particular reference to marrow-stem kale. Rep. Pl. Breed. Inst., 1965-66, 7-34.

THOMPSON, K. F., AND HOWARD, H. w. 1959. Self-incompatibility in marrow-stem kale, Brassica oleracea var. acephala. II. Recognition of plants homozygous for $S$ alleles. 7. Genet., 56, 325-340.

THOMPSON, K. F., AND TAYLOR, J. P. 1966a. Non-linear dominance relationships between $S$ alleles. Heredity, 21, 345-362.

THOMPSON, K. F., AND TAYLOR, J. P. 1966 $b$. The breakdown of self-incompatibility in cultivars of Brassica oleracea. Heredity, 21, 637-648.

THOMPSON, K. F., AND TAYLOR, J. P. 1971. Self-compatibility in kale. Heredity, 27, 459-471.

WALlACE, D. H., AND NASRAllah, M. E. 1968. Pollination and serological procedures for isolating incompatibility genotypes in the Crucifers. Cornell University Agric. Expt. Station, Memoir 406. pp. 23. 